\title{
THE LEGAL REGULATION OF POLITICAL PARTIES IN LATIN AMERICA: PUBLIC FUNDING AND INTERNAL DEMOCRACY
}

\begin{abstract}
In this paper I present a comparative analysis of the legal regulation of political parties in Latin America. I examine the legislation in force by early 2020 considering two elements: public funding and internal democracy. The results show that all the countries in the region grant public funding for political parties, and that in all the countries except Brazil political parties must be internally democratic. Additionally, taking into account characteristics of the regulation not considered in previous studies, this study reveals that in most of the countries there is public funding for parties that must be allocated to political research and training, and that in most of the cases there is a procedure for party members to appeal against the party leaders' decisions. Finally, I show that the regulation of parties in the region could improve the parties' performance as decision makers and strengthen the political participation and representation of the citizenship.
\end{abstract}

\section{Keywords}

Law on political parties - Latin America - Public funding for political parties - intraparty democracy

\footnotetext{
* Universidad Nacional Atonóma de Mexico; jorgegfloresd@outlook.com
} 


\section{INTRODUCTION}

Since the emergence of modern democracy, the relationship between the state and political parties has completely changed: from being viewed with suspicion, and in some countries even rejected and legally banned, to being desired, protected, and subjected to exhaustive legal regulation. This topic, however, has only recently been the subject of systematic studies.

There are academic contributions that, from a comparative approach, show the characteristics of the different national legislations and the contrasts between them, either at global ${ }^{1}$ or regional level. ${ }^{2}$ In the specific case of Latin America there are studies which compare the regulation of political parties as a whole ${ }^{3}$ while others focus their analysis on one level or element, such as the constitutional rules, ${ }^{4}$ the requirements for legal recognition, ${ }^{5}$ or public funding. ${ }^{6}$ However, as studies on the constitutional change have shown, ${ }^{7}$ this is a region characterized by a continuous modification of the law, and the regulation of political parties is not an exception. For this reason a periodic analysis on the state of the question is required. Thus, I present a comparative overview of the regulation

${ }^{1}$ For example: K. Janda, Political Parties and Democracy in Theoretical and practical Perspectives. Adopting Party Law, National Democratic Institute for International Affairs, 2005; M. Ohman, Political Finance Regulations around the World, IDEA International, 2012.

2 For example: I. Biezen, H. Napel, Regulating Political Parties. European Democracies in Comparative Perspective, Leiden University Press, 2014; or F. Casal Bértoa and I. van Biezen (eds.), The Regulation of Post-Communist Party Politics, Routledge, 2018.

${ }^{3}$ For example: D. Zovatto (ed.), Regulación jurídica de los partidos políticos en América Latina, UNAM, 2006 and F. Molenaar, Latin American regulation of Political Parties: Continuing trends and Breaks with the Past, Working Paper Series on The Legal Regulation of Political Parties, no. 17, European Research Council/ University of Leiden, 2012.

${ }^{4}$ D. Degiutti, Los partidos políticos en las constituciones de América Latina, Trabajo presentado en el Quinto Congreso Uruguayo de Ciencia Política, October 2014.

${ }_{5}$ Y. Su, Party registration rules and party systems in Latin America, in Party Politics, 2/2015. vol. 2.

${ }^{6}$ P. Gutiérrez, D. Zovatto (eds.), Financiamiento de los partidos politicos en América Latina, UNAM, 2011.

7 G. Negretto, Making Constitutions. Presidents, Parties, and Institutional Choice in Latin America, Cambridge University Press, 2013. 
of political parties in 18 Latin American countries (Argentina, Bolivia, Brazil, Chile, Colombia, Costa Rica, Ecuador, El Salvador, Guatemala, Honduras, Mexico, Nicaragua, Panama, Paraguay, Peru, Dominican Republic, Uruguay, and Venezuela). The analysis is based on an original database ${ }^{8}$ built by the author with the laws in force by early-2020. This paper focuses on two elements: Public Funding and Internal Democracy. I selected these elements because they have a high impact on the political parties as organizations, on their relationship with the state, and on state democracy. Additionally, I study some elements not considered before in the comparative analysis of public funding and internal democracy in the region: the public financing labelled to political training and research, and the appellate procedures against party decisions. Finally, I present a brief analysis of the potential implications of the dominant model in the region.

\section{From Rejection to Constitutionalization: the Political Parties in the LaW}

The political parties emerged from the instauration of democratic procedures in modern states. The popular elections and the parliamentary work created organizational needs which were met by the parties, ${ }^{9}$ and today there is a consensus in the idea that democracy is unthinkable without these organizations. However, at the beginning, the political parties were viewed with contempt and only were accepted as legitimate political actors through a slow and tortuous process.

According to the orthodox or "Hamiltonian view", followed in the United States at the end of the XVIII century and the first half of the XIX, the political parties constitute "simply organizations formed to advance various special interests against the common public interest."10 Meanwhile, in Europe, authors like Bolingbroke or Hume held a similar

${ }^{8}$ Latin American Regulation of Political Parties Database, 2020.

9 M. Ostrogorski, La democracia y los partidos políticos, Trotta, 2008, M. Duverger, Los partidos politicos, FCE, 2006.

${ }^{10}$ R. Hofstadter, The Idea of a Party System: The Rise of Legitimate Opposition in the United States 1780-1840, University of California Press, 1969, p. 17. 
view claiming that the political parties damage the unity of the state. ${ }^{11}$ The negative opinion towards them had legal implications. In some local legislations in the United States and in countries like France or Colombia political parties were legally banned. ${ }^{12}$

However, the extinction of parties was impossible, and as a result of the recognition of the association right-demanded by the social movements of the XIX century- political parties were tolerated. Then, gradually the negative view about them changed. They were not considered anymore to be an intrinsic evil that disturbs the common good by creating undesired divisions in society. In the United States, republican leaders embraced the oppositional character of their party, claiming that parties "are unknown in despotic countries." 13

The adoption of a new conception of political parties allowed their legal recognition, which in the beginning only implied adopting the term political party into the electoral law without providing a doctrinal definition or adjudicating meaningful rights or duties to them. Through the XX century and the beginning of the XXI, however, the legislation on parties was significantly increased. The political parties began to be regarded as indispensable participants in a democratic state and they were incorporated into the constitutions of many states. In Europe, after the World War II a process of party constitutionalization started, which was particularly acute following the third (in Southern Europe in the 1970s) and fourth (in post-communist Central and Eastern Europe in the early 1990s) waves of democratization. As a result, 28 out of 33 European democracies have so far recognized political parties at the constitutional level. ${ }^{14}$

11 G. Sartori, Partidos y Sistemas de Partidos, Alianza, 2005, p. 27-42.

12 A. Hernández, "Regulación jurídica de los partidos políticos en Colombia", in D. Zovatto (ed.), Regulación jurídica de los partidos políticos en América Latina, UNAM, 2006, J. Hernández, "La delimitación del concepto de partido político. Las teorías sobre el origen y la evolución de los partidos", C. Martínez Cuadrado, M. Márquez (eds.), Partidos políticos y sistemas de partidos, Trotta, 2012.

${ }^{13}$ Hofstadter, supra note 10, p. 269.

${ }^{14}$ I. Biezen, "The constitutionalization of Political Parties in Post-war Europe", Biezen, T. Napel (eds.), Regulating political parties. European democracies in comparative perspective, Leiden University Press, 2014, p. 95. 
In Latin America the political parties began to be incorporated into the electoral law in the second half of the XIX century. It is worth noting that this implies that they were recognized as legitimate actors. However, in the beginning the legal incorporation was just nominal, limited to using the term without providing meaningful rights or duties for them. Then, in the 1930s the political parties began to acquire constitutional rank (table $1)$, which means that their recognized importance was strengthened. Although in a first phase the constitutionalization of the political parties was limited to a nominal recognition, in a second one, which took place centrally in the 1980s and 1990s, meaningful rights and duties were incorporated. Among them, two have a prominent position: public funding and intra-party democracy.

Table 1. The Constitutionalization of Political Parties in Latin America

\begin{tabular}{llllll}
\hline Country & Year & Country & Year & Country & Year \\
\hline Peru & 1933 & Panama & 1946 & Mexico & 1963 \\
\hline Uruguay & 1934 & Venezuela & 1947 & Paraguay & 1967 \\
\hline $\begin{array}{l}\text { Dominican } \\
\text { Republic }\end{array}$ & 1942 & Costa Rica & 1949 & Chile & 1970 \\
\hline Ecuador & 1945 & El Salvador & 1950 & Nicaragua & 1979 \\
\hline Guatemala & 1945 & Honduras & 1957 & Colombia & 1991 \\
\hline Brazil & 1946 & Bolivia & 1961 & Argentina & 1994 \\
\hline
\end{tabular}

Source: Flores, supra, note 23, and author's review of the legislation in El Salvador.

Nowadays in ten constitutions of the region the political parties have the right to receive direct public funding, and in thirteen they have the duty to be internally democratic (table 2). 
Table 2. Public Funding and Internal Democracy in the Constitutions of Latin America

\begin{tabular}{llllll}
\hline Country & $\begin{array}{l}\text { Public } \\
\text { Funding }\end{array}$ & $\begin{array}{l}\text { Internal } \\
\text { Democracy }\end{array}$ & Country & $\begin{array}{l}\text { Public } \\
\text { Funding }\end{array}$ & $\begin{array}{l}\text { Internal } \\
\text { Democracy }\end{array}$ \\
\hline Argentina & Yes & Yes & Honduras & Yes & No \\
\hline Bolivia & No & Yes & Nicaragua & No & No \\
\hline Brazil & Yes & No & Mexico & Yes & No \\
\hline Chile & No & Yes & Panama & Yes & Yes \\
\hline Colombia & Yes & Yes & Paraguay & No & Yes \\
\hline Costa Rica & Yes & Yes & Peru & No & Yes \\
\hline Ecuador & Yes & Yes & Dominican & No & Yes \\
& & & Republic & & \\
\hline El Salvador & Yes & Yes & Uruguay & No & Yes \\
\hline Guatemala & Yes & No & Venezuela & No & Yes \\
\hline
\end{tabular}

Source: supra, note 8 .

\section{PUBlic Funding}

The introduction of public funding for political parties was the result of two factors: 1) the economic crisis of these organizations, and 2) the new normative idea regarding them.

In the second half of the XX century the cost of political participation increased significantly owing to the emergence of modern mass media (radio and TV), which entailed hiring expensive spots and expensive teams in political marketing. At the same time, the political parties experienced a serious decrease in their militancy, which had a negative impact on their incomes from members' contributions and deprived them to a large extant of voluntary work. In such a situation the political parties, as legislators, changed the law to allocate to themselves state resources. ${ }^{15}$

${ }^{15}$ R. Katz, P. Mair, "Changing Models of Party Organization and Party Democracy: The Emergence of the Cartel Party", in Party Politics, 1995, vol. 1, no. 1, I. Biezen, "Political Parties as Public Utilities", in Party Politics, 2004, vol. 10, no. 6, Sage. 
The allocation of state funds for political parties was justified based on the new normative idea according to which political parties are required for the health of the democratic system. ${ }^{16}$ Political parties express plurality in society, and they are unavoidable in a democratic system because, among other things, they recruit and train political elites, aggregate and articulate political interests, organize dissent and opposition, and present candidates for public office. ${ }^{17}$ In addition, the advocates of public funding for political parties claimed that it would disclose the resources used by the parties, it would balance the competition among them, and it would free parties from big donors, ${ }^{18}$ reducing in this way the probability of political corruption. In fact, as Koß states, the more widespread is the belief that public funding prevents corruption, the more likely it is to be approved by parliaments. ${ }^{19}$

The allocation of direct public funding for political parties has been almost unanimously adopted in Europe and Latin America. According to Piccio and van Biezen, only three European countries (Malta, Switzerland, and Ukraine) have no rules on the subject at the national level, ${ }^{20}$ and Bolivia is the only democratic Latin American country ${ }^{21}$ which does not grant direct public funding for political parties. ${ }^{22}$ In this region some

16 Biezen, supra note 15.

17 R. Dalton, M. Wattenberg, "Unthinkable Democracy: Political Change in Advanced Industrial Democracies", in Dalton, Wattenberg (Eds), Parties without Partisans. Political Change in Advanced Industrial Democracies, Oxford University Press, 2000, p. 6-8.

$18 \mathrm{~J}$. Woldenberg, Historia mínima de la transición a la democracia en México, COLMEX, 2012, p. 115.

${ }^{19}$ Other factors to take into account are: The institutional veto points, and the political parties' goals M. Koß, The Politics of Party Funding: State Funding to Political Parties and Party Competition in Western Europe, Oxford University Press, 2011.

${ }^{20}$ D. Piccio, Biezen, "More and More Inclusive Regulation: The Legal Parameters of Public Funding in Europe", in Boatright, Robert (Ed.), The Deregulatory Moment? A Comparative Perspective on Changing Campaign Finance Laws, University of Michigan Press, 2015, p. 205.

${ }^{21}$ Owing to the forced exit of Morales from the presidency there is uncertainty on the future of this country. However, by the time of writing this research note, Bolivia was still considered a democracy.

22 Venezuela is another Latin American country which does not grant direct public funding for political parties. However, it has been an authoritarian country since 2017, The Global State of Democracy. Addressing the Ills, Reviving the Promise, International IDEA, 2019. 
countries established the allocation of state resources for parties early, but it began to be a regional trend in the 1970s (table 3).

Table 3. Year of Introduction of Public Funding for Political Parties in Latin America

\begin{tabular}{llllll}
\hline Country & Year & Country & Year & Country & Year \\
\hline Uruguay & 1928 & Nicaragua & 1974 & Colombia & 1985 \\
\hline Costa Rica & 1949 & Mexico & 1977 & Paraguay & 1990 \\
\hline Argentina & 1961 & Ecuador & 1978 & Bolivia & 1997 \\
\hline Brazil & 1965 & Honduras & 1981 & $\begin{array}{l}\text { Dominican } \\
\text { Republic }\end{array}$ & 1997 \\
\hline Panama & 1972 & El Salvador & 1983 & Peru & 2003 \\
\hline Venezuela & 1973 & Guatemala & 1985 & Chile & 2003 \\
\hline
\end{tabular}

Source: Flores, supra, note 23, and author's review of the legislation in El Salvador.

Since its establishment, the norms on public funding for parties have notably expanded. In countries like Mexico, it began as an indirect support delivered in election years consisting of the allocation of electoral material to increase electoral propaganda, tax exemption, and space in the state mass media (radio and TV). Its objective was to support the electoral participation of political parties. However, soon after, it implied the allocation of direct funding, which in turn became permanent (not limited to the election years), ${ }^{23}$ and its objective was to support, not only the electoral activities of the political parties, but also bureaucratic organization, political training, research, etc. Only in Bolivia did public funding go backwards, but the country recently has taken measures which apparently put it again in the regional trend. ${ }^{24}$ Thus, almost every Latin

${ }^{23}$ J. Flores, La génesis de la regulación jurídica de los partidos políticos en América Latina: Bolivia, Brasil y México en perspectiva comparativa, PhD. Dissertation in Political Science, UNAM, 2017, p. 126-164.

${ }^{24}$ In Bolivia the direct public funding for political parties in election year was established in 1997; and in 1999 it was extended to be delivered every year (not only in the election year). However, in 2008 every kind of state funding for parties was banned. Thus, 
American country grants permanent and direct public funding for its parties, and in just few cases it is limited to electoral activities in election years or to indirect support (table 4). In Europe nowadays public funding is the primary source of incomes of political parties, ${ }^{25}$ and apparently Latin America is following this path. Today in this region state resources represent more than $50 \%$ of electoral expenditure in Chile, Costa Rica, Mexico, Nicaragua, and Uruguay. ${ }^{26}$

Table 4. Public Funding for Political Parties in Latin America

\begin{tabular}{llllll}
\hline Country & $\begin{array}{l}\text { Permanent } \\
\text { or Electoral }\end{array}$ & $\begin{array}{l}\text { Direct or } \\
\text { Indirect }\end{array}$ & Country & $\begin{array}{l}\text { Permanent } \\
\text { or Electoral }\end{array}$ & $\begin{array}{l}\text { Direct or } \\
\text { Indirect }\end{array}$ \\
\hline Argentina & Both & Both & Honduras & Both & Both \\
\hline Bolivia & Both & Indirect & Nicaragua & Electoral & Both \\
\hline Brazil & Both & Both & Mexico & Both & Both \\
\hline Chile & Permanent & Both & Panama & Both & Both \\
\hline Colombia & Both & Both & Paraguay & Both & Both \\
\hline Costa Rica & Both & Direct & Peru & Both & Both \\
\hline Ecuador & Both & Both & $\begin{array}{l}\text { Dominican } \\
\text { Republic }\end{array}$ & Both & Both \\
\hline El Salvador & Permanent & Indirect & Uruguay & Both & Both \\
\hline \multicolumn{7}{l}{ Electoral } & Direct & & & \\
\hline Guatemala & Both & Both & Venezuela & Electoral & Indirect \\
\hline
\end{tabular}

*If the Electoral Council approves it.

Source: supra, note 8 .

In the region public funding for parties is allocated following two criteria: 1) egalitarian and 2) proportional. According to the former the

the political parties do not receive direct public funding Ibid. p.43-84. The recently passed law of political organizations (Ley de Organizaciones Políticas, Bolivia, 2018), however, grants political parties indirect subventions to political advertising during the campaign for public office and to political training of its members in years between elections.

${ }^{25}$ Piccio, Biezen, supra note 20, p. 212

${ }^{26}$ K. Casas, D. Zovatto, The Cost of Democracy. Essays on Political Finance in Latin America, OEA, 2016, p. 77. 
political parties receive the same amount regardless of their size or representation, while based on the latter each party receives an amount depending on the voting or representation it gets in the elections. There are important differences in the region concerning the criteria used to allocate the state subsidies, of which the most important one is the representation each party has. In fact, in almost half of the countries it is the only one to consider. And in just a few countries it is delivered considering mainly an egalitarian criterion (table 5). Arguably, state funding which is equally allocated benefits the smallest parties at the expense of the bigger ones, but by doing so promotes electoral competitiveness.

Table 5. Criteria for the Allocation of Public Funding for Political Parties in Latin America

\begin{tabular}{llllll}
\hline Country & $\begin{array}{l}\text { Equally } \\
\text { Divided }\end{array}$ & $\begin{array}{l}\text { Proportionally } \\
\text { Divided }\end{array}$ & Country & $\begin{array}{l}\text { Equally } \\
\text { Divided }\end{array}$ & $\begin{array}{l}\text { Proportionally } \\
\text { Divided }\end{array}$ \\
\hline Argentina & $20 \%$ & $80 \%$ & Honduras & $0 \%$ & $100 \%$ \\
\hline Bolivia* & - & - & Nicaragua & $0 \%$ & $100 \%$ \\
\hline Brazil & $5 \%$ & $95 \%$ & Mexico & $30 \%$ & $70 \%$ \\
\hline Chile & $0 \%$ & $100 \%$ & Panama & $25 \%$ & $75 \%$ \\
\hline Colombia & $25 \%$ & $75 \%$ & Paraguay & $0 \%$ & $100 \%$ \\
\hline Costa Rica & $0 \%$ & $100 \%$ & Peru & $40 \%$ & $60 \%$ \\
\hline Ecuador* & $50 \%$ & $35 \%$ & Dominican & $100 \%$ & $0 \%$ \\
\hline El Salvador & $0 \%$ & $100 \%$ & Republic* & & \\
\hline Guatemala & $0 \%$ & $100 \%$ & Uruguay & $0 \%$ & $100 \%$ \\
\hline
\end{tabular}

Ecuador: The remaining 15\% to the Institute of Political Research and Analysis. Dominican Republic: $80 \%$ equally divided among the parties with more than $5 \%$ of voting in the last election; $12 \%$ equally divided among the parties with more than $1 \%$ and less than $5 \%$ of voting in the last election; $8 \%$ equally divided among the parties with more than $0.01 \%$ and less than $1 \%$ of voting in the last election. Bolivia: The percentage depend on the provisions approved by the Pluri-National Electoral Body. Venezuela: The percentage depend on the provisions approved by the Electoral Council.

Source: supra note 8. 
The allocation of state financing for political parties usually began as an indirect funding - tax exemption, time on mass media, etc. delivered during the election year. However, it later implied the direct and permanent allocation of financial support. To date, in the region, 12 countries (2/3 of the total) have followed this path. The exceptions encompass countries like Nicaragua, where the public funding for parties is restricted to the election year, or El Salvador, where the electoral funding is direct while the permanent one is indirect.

Table 6. Percentage of Public Funding Labelled to Political Training and Research

\begin{tabular}{llllll}
\hline Country & Percentage & Country & Percentage & Country & Percentage \\
\hline Argentina & $20 \%$ & Ecuador & $15 \%$ & Panama* & $50 \%$ \\
\hline Bolivia* & $100 \%$ & El Salvador & $\begin{array}{l}\text { Not } \\
\text { specified }\end{array}$ & Paraguay & $\begin{array}{l}\text { Not } \\
\text { specified }\end{array}$ \\
\hline Brazil & $20 \%$ & Guatemala & $30 \%$ & Peru & Up to $50 \%$ \\
\hline Chile * & $10 \%$ & Honduras & $10 \%$ & $\begin{array}{l}\text { Dominican } \\
\text { Republic }\end{array}$ & $10 \%$ \\
\hline Colombia & $15 \%$ & Mexico & $3 \%$ & Uruguay & Not specified \\
\hline $\begin{array}{l}\text { Costa } \\
\text { Rica* }\end{array}$ & $\begin{array}{l}\text { Not } \\
\text { specified }\end{array}$ & Nicaragua & $\begin{array}{l}\text { Not } \\
\text { specified }\end{array}$ & Venezuela & $\begin{array}{l}\text { Not } \\
\text { specified }\end{array}$ \\
\hline
\end{tabular}

Bolivia: The state funding delivered during the years between elections must be allocated to financing training courses, workshops, conferences, etc., to party members; and to financing research directed by the Electoral State Body. Chile: The state funding delivered during the years between elections must be used to encourage the political participation of women. Costa Rica: Each party decides by itself. Panama: 50\% of the annual contribution based on voting.

Source: supra note 8 .

Permanent public funding has supported the development of professional bureaucratic party structures, allowing and on occasions encouraging the political parties to expand their non-electoral activities. In this regard, it is worth noting that in two thirds of the countries in the region there is a percentage of the public funding that must be used in financing members' and leaders' training and in financing research projects (table 6). This action is intended to improve the performance 
of the political parties as decision makers. Apparently, this is becoming the new regional trend. However, it is not unanimously adopted and, as in other aspects, there are remarkable differences among countries. In Bolivia, for example, it is the only kind of state funding allowed, while in others, like Mexico, it represents only 3\% of the total amount received by the parties.

In sum, the current picture shows that public funding for political parties is widely established in Latin America. In addition, it seems that the rules are expanding, beginning to encompass the spending pattern of public money the political parties receive between elections. It is worth noting that these rules are still a subject of debate. This point can be illustrated by the case of Mexico, in which, owing to dissatisfaction with the political parties, it has been proposed to reduce or even to eliminate public funding for parties..$^{27}$ In this regard, it should be taken into account that, whereas it is healthy to rethink and adjust the institutional system, countries like Bolivia show that eliminating public funding is associated with an erosion of democracy ${ }^{28}$.

\section{INTRA-PARTY DEMOCRACY}

The latest global trend regarding political parties and the law is the regulation of their internal life. Historically, political parties have been considered private organizations, since they emerge from the will of the citizens based on political organization and participation rights. For this reason, the state respected their autonomy, allowing them to behave internally as they preferred, without any interference.

However, the idea about the nature of political parties and the relationship they must keep with the state has changed since the end of the Second World War. In Europe, the experience of authoritarian governments (Nazi Germany and Fascist Italy) promoted a new view concerning political parties and the State, according to which the State must ban those parties that follow an undemocratic ideology seeing

${ }^{27} \mathrm{~J}$. Cervantes, "Morena presenta iniciativa para reducir $50 \%$ el gasto ordinario de los partidos políticos", Proceso. March, 5, 2019.

${ }^{28}$ Flores, supra note 23. 
that they are a risk to the preservation of state democracy. Then, this democratic intolerance evolved from only banning parties sustaining an undemocratic ideology to requiring that those parties legally recognized were internally democratic. To the supporters of the new view on political parties, it would be illogical to expect democratic behaviour from them in the political system if they were not democratic within..$^{29}$ Following Biezen and Piccio, ${ }^{30}$ in Europe those democracies that come from an autocracy are more willing to regulate the internal life of political parties (e.g. Germany and Spain) than those with the oldest democratic systems (e.g. United Kingdom and Norway).

Table 7. Year of the First Regulation of Intra-Party Affairs in Latin America

\begin{tabular}{llllll}
\hline Country & Year & Country & Year & Country & Year \\
\hline $\begin{array}{l}\text { Dominican } \\
\text { Republic }\end{array}$ & 1962 & Chile & 1987 & Nicaragua & 2000 \\
\hline Argentina & 1965 & Paraguay & 1990 & El Salvador & 2003 \\
\hline Brazil & 1965 & Costa Rica & 1991 & Peru & 2003 \\
\hline Panama & 1978 & Uruguay & 1997 & Honduras & 2004 \\
\hline Colombia & 1985 & Bolivia & 1999 & Mexico & 2007 \\
\hline Guatemala & 1985 & Venezuela & 1999 & Ecuador & 2009 \\
\hline
\end{tabular}

Source: Flores, supra note 23, and author's review of the legislation in El Salvador.

In Latin America the internal life of political parties began to be regulated in the 60s. However, it was not until the 90s and the first decade of the XXI century that such regulation spread to the whole region (table 7). To date, every single country in the region but Brazil -which in the 60 s adopted a system of state regulation on political parties' internal

29 I. Biezen, Constitutionalizing Party Democracy: The Constitutive Codification of Political Parties in Post-War Europe, Working Paper Series on the Legal Regulation of Political Parties, $\mathrm{N}^{\circ}$ 3. European Research Council/ University of Leiden, 2009, Biezen, supra note 14.

${ }^{30}$ I. Biezen, D. Piccio, "Shaping Intra-Party Democracy: On the Legal Regulation of Internal Party Organizations", in W. Cross, R. Katz (eds.). The Challenges of Intra-Party Democracy, Oxford University Press, 2013. 
affairs, but eliminated it in the $80 \mathrm{~s}^{31}$ - has some kind of state regulation on internal party life, and establishes in the constitution or in the secondary legislation that political parties must be internally democratic.

As Cross and Katz state: "Like democracy itself, the definition of intraparty democracy is essentially contestable [...] there is no single, agreed upon definition of what it means to be internally democratic". Yet, "the ultimate questions remain to what extent, how, and in which aspects of party life the members are able to control what their party does". 32

Table 8. Legal Method of Selecting Candidates for Public Office in Latin America

\begin{tabular}{ll}
\hline Method & Countries \\
\hline Closed Primaries & $\begin{array}{l}\text { Bolivia*, El Salvador, Panama, Paraguay, } \\
\text { and Venezuela }\end{array}$ \\
\hline Opened Primaries & Argentina, Honduras, Peru, and Uruguay \\
\hline Convention of Delegates & Guatemala \\
\hline Various Options & Ecuador, and Dominican Republic \\
\hline Not specified & $\begin{array}{l}\text { Brazil, Colombia, Chile, Costa Rica, Mexico, } \\
\text { and Nicaragua }\end{array}$ \\
\hline
\end{tabular}

Bolivia: For President and Vice-President. Ecuador: Closed or Opened Primaries, and Convention of Delegates. Dominican Republic: Closed Primaries, Convention of Delegates, Selection by Party Leaders, and Opinion Polls.

Source: supra note 8 .

In Latin America the legal regulation of intra-party democracy has focused on the candidate and leader selection methods, and on the appellate procedures against party decisions. In most of the countries there is a specific method that parties must use to select their candidates. It could be Closed Primaries: direct election where all party members can vote; Opened Primaries: direct election where all citizens, not just party

31 Flores, supra note 23.

${ }^{32}$ W. Cross and R. Katz, "The Challenges of Intra-Party democracy", in W. Cross, R. Katz (eds.). The Challenges of Intra-Party Democracy, Oxford University Press, 2013, p. 2 and 10. 
members, can vote; or Convention of Delegates: indirect election where the delegates, elected by party members, can vote. The most common method in the region is Closed Primaries. It is used in five countries. Opened Primaries are used in four countries and Convention of Delegates in one; in two more cases the political parties could choose among different options, and in the remaining six countries there is no specific method (Table 8).

In addition, in seven countries the electoral authority is in charge of organizing the intra-party process of candidate selection, while in two it just oversees the process organized by the party itself, and in the rest (nine cases) the parties are free in this regard (table 9).

Table 9. Is the Intra-Party Process of Selecting Candidates for Public Office Organized or Overseen by the State?

\begin{tabular}{ll}
\hline State Role & Countries \\
\hline $\begin{array}{l}\text { Organize the Intra-party } \\
\text { Process }\end{array}$ & $\begin{array}{l}\text { Bolivia*, Chile*, Honduras, Panama, Peru, } \\
\text { Dominican Republic, and Uruguay }\end{array}$ \\
\hline $\begin{array}{l}\text { Oversee the Intra-party } \\
\text { Process }\end{array}$ & Argentina*, Ecuador \\
\hline None & $\begin{array}{l}\text { Brazil, Colombia, Costa Rica, El Salvador, } \\
\text { Guatemala, Mexico, Nicaragua, Paraguay, } \\
\text { Venezuela }\end{array}$ \\
\hline
\end{tabular}

Bolivia: For President and Vice-President. Chile: If the party conducts primary elections, Argentina: By request of the involved party

Source: supra note 8 .

Additionally, in some cases there are specific methods that political parties must use to select their leaders. However, in the region only two countries have established this rule: El Salvador (Closed Primaries) and Guatemala (elected by National Assembly).

Furthermore, in two countries (Panama and Mexico) the Leaders Selection Process is organized by the electoral authority ${ }^{33}$ and in other

${ }^{33}$ In Mexico the electoral body organizes it by request of the involved party. 
four (Bolivia, Costa Rica, Ecuador, and Peru) the electoral authority oversees the process. ${ }^{34}$ In the remaining cases (14 countries) the party organizes it by itself.

Whereas the direct intervention of the state, organizing or overseeing the intra-party processes of selecting candidates or party leaders, does not occur in all the Latin American countries and, in fact, is today a rare event, most of the political parties in the region are anyway accountable for the decisions they make. Twelve Latin American countries establish appellate procedures to protect partisan rights. In the other six countries there are no explicit appellate procedures, but state intervention is also not banned and, as in Mexico, ${ }^{35}$ by interpreting the constitution, the electoral authority might intervene in the parties' internal life (table 10). In fact, Brazil is the only democratic country in the region that explicitly bans state intervention in the internal life of political parties. ${ }^{36}$

Table 10. Is There an Appellate Procedure Against Party Decisions?

\begin{tabular}{ll}
\hline Yes/No & Countries \\
\hline Yes & Argentina, Bolivia, Chile, Costa Rica, Ecuador, \\
& El Salvador, Guatemala, Honduras, Mexico, \\
& Nicaragua, Panama, and Uruguay \\
\hline No & Brazil \\
\hline No Explicit Reference & Colombia, Paraguay, Peru, Dominican \\
& Republic, and Venezuela \\
\hline
\end{tabular}

Source: supra note 8 .

So far, not all Latin American countries have passed legal reforms on intra-party democracy - concerning candidate and leader selection processes, and appellate procedures. However, with the exception of Brazil, there have been no counter-reforms either. Consequently, it seems

${ }^{34}$ In Peru the electoral body oversees it by request of the involved party.

${ }^{35}$ In Mexico, by means of an Electoral Court Interpretation which took place in 2003 the intra-party processes began to be subject to judicial review. However, in 2007 this interpretation was established in the constitution Flores, supra note 23.

${ }^{36}$ Ibíd. 
more probable that the region will continue this tendency rather than the contrary.

\section{The Implications of the Legal Regulation of Political Parties in Latin America}

The expansion of state involvement in political parties - by means of financing their activities and/or intervening in their internal processeshas generated debate on the nature of these organizations and on the consequences over the democratic system.

As stated above, the political parties emerged from civil society. They are voluntary organizations that result from the organizational needs inherent in a representative democracy, and from the recognition of the rights to participation and organization. Thus, historically their nature has been closer to civil society than to the state. However, the relevant role they fulfil in the correct working of democracy has justified wide state intervention. Thereby, from the second half of the XX century the trend in the democratic world has been marked by the public financing of political parties and by the regulation of their internal life. Hence, in most of the democratic countries, the political parties increasingly resemble state bureaucratic bodies. However, being the organizations that present candidates for public office, they cannot avoid their role as intermediaries between the state and the citizen. In view of this fact, new terms have emerged to describe their nature, such as "semi-state agencies" 37 or "public utilities". ${ }^{38}$

The newest trends regarding the regulation of political parties may have important implications for political participation and representation. On the basis of the data presented in this paper it could be suggested that the regulation of political parties in Latin America may potentially promote an opening up of these organizations towards the participation of civil society and it also may potentially improve their role as decision makers. In almost every country in the region the political parties receive

\footnotetext{
37 Katz, Mair, supra note 15, p. 16.

38 Biezen, supra note 15 , p. 705.
} 
state subsides, which are in some countries the main source of party income. In a region characterized by an acute economic inequality, the fact that the political parties do not depend on the money of private donors might free them from the overwhelming eventual influence of a few big donors, allowing a more democratic internal decision making. Additionally, considering that in most of the countries there is a percentage of public funding labelled for political training and research, it could be suggested that the legislation in the region may help to improve the political parties' performance in the government.

Finally, in the region most of the legislation on parties regulates their internal processes. Every country but Brazil has established in law that political parties must be democratic, and many legislations force political parties to select their candidates and leaders through the direct or indirect voting of their members, most of them establishing an appellate procedure which could be used by party members to ask for the judicial revision of the internal processes in the case of alleged violation of their rights. This kind of legislation limits the autonomy and liberty of the political parties: however, it is established with the aim of protecting the members' right to participate in intra-party decisions.

Thus, a general review of the institutional systems which regulate the working of political parties in Latin America suggests that it has the potential to strengthen democratic participation and representation and to improve their role as decision makers. However, evaluating the actual effects of the regulation of the parties is the research subject of a pending empirical analysis.

\section{CONCLUSIONS}

In this paper I have conducted a comparative analysis of the regulation of political parties in Latin America considering two elements: Public Funding and Internal Democracy. The analysis revealed that all the countries grant some form of public funding for political parties, and in most of the cases it is permanently allocated. In addition, all the countries, except Brazil, establish by law that the political parties must be internally democratic and in most of the cases there is a specific method of selecting candidates for public offices. 
However, the main contribution of this paper rests on the study of elements not considered in previous works. Regarding public funding it was revealed that in most of the countries there is a percentage of public funding that must be allocated to political training and research. Besides, regarding intra-party democracy, it was revealed that in most of the cases there is a procedure to request the intervention of the state judicial bodies against alleged violations of partisan rights.

Finally, it is worth noting that the characteristics of the Latin American legislation on political parties suggest that it has the potential to improve their role as decision makers and to strengthen the political participation and representation of the citizenship. Thus, the next step must be the empirical study of the intra-party processes to reveal the actual impact of the regional legislation. 
